\title{
Lead Exposure on Blood Pressure and Lipid Parameters Alteration among People around Bus Terminal in Yogyakarta
}

\author{
Sani Rachman Soleman*, Shafira Alifiana Andini and Larasati Chayaning Edi \\ Faculty of Medicine, Department of Public Health, Universitas Islam Indonesia, \\ Yogyakarta - 55584, Indonesia; sani.rachman@uii.ac.id, alifianashafira@gmail.com, larasaticahya97@gmail.com
}

\begin{abstract}
Lead is generated as residual progress of vehicle or factory process. The excessive amount of lead has several impacts on human health system namely on cardiovascular, respiratory, endocrine and metabolic system through damaging enzymatic process and Reactive Oxygen Species (ROS). The aim of this study is to search the correlation of lead exposure on blood pressure and lipid parameters alteration among people around bus terminal in Yogyakarta. This study is a cross sectional research design. According to calculation of sample size, 71 respondents had fulfilled the inclusion criteria such as: Agree to be respondents, 6 hours fasting prior to take data, age $>18$ years old and had history of staying nearby bus terminal for more than one year. The variables divided into two, independent variable is lead exposure and dependent variables are SBP and DBP meanwhile lipid parameters such as LDL, HDL and TG. Those variables were analyzed by linier regression. Based on linier regression was obtained that SBP ( $p$ value $0.004, r 0.33$ and $R$ square 0.11 ), DBP ( $p$ value $0.001 \mathrm{r} 0.37$ and R square 0.138 ), LDL ( $\mathrm{p}$ value $0.002 \mathrm{r} 0.35$ and R square 0.128 ), HDL ( $\mathrm{p}$ value $0.001, \mathrm{r} 0.37$ and $\mathrm{R}$ square 0.139 ) and TG (p value 0,002 , r 0.36 and R square 0.130 ). The result of study was found that lead exposure contributed on blood pressure and lipid parameters alteration among people around bus terminal in Yogyakarta.
\end{abstract}

Keywords: Blood Pressure, Bus Terminal, Lead Exposure, Lipid Parameter

\section{Background}

Lead is a chemical substances with specific characteristic such as dull, silver-gray metal, corrosion-resistant and soft ${ }^{1}$. It had been used widely to be used on pipe, pottery, insecticide, anti knocking additive for petrol, battery, paints, cable sheathing and many more ${ }^{1,2}$. The pollution of lead in the air was generated by residual process vehicle that spreading into atmosphere, soil and water ${ }^{1-3}$. The impact of lead pollution can accumulate into human body resulting teratogenic effect, carcinogenic and disturbing physiological process, meanwhile it could also destroy marine environmental ecosystem through defilement process in water ${ }^{1,4}$. Lead enters human body through three mechanism; skin contact, respiratory and oral pathways ${ }^{1,5}$. Long term exposure of lead in human can affect children, pregnant women, mining workers and industrial employees that appearing symptoms based on organ target ${ }^{1}$. The most common organ target are lung, liver, endocrine-metabolic and even heart and vascular systems ${ }^{4-6}$.
Lead induces cardiovascular disease via increasing the oxidative and inactivating endogen nitrite oxide that caused by Reactivated Nitrite Oxide (RNO), increasing symphatic stimuli, angiotensin converting enzyme, plasma reninangiotensin-aldosteron, natrium retention as result of lead accumulation in blood vessel ${ }^{7}$. Chronic lead exposure induces reactivated oxidative stress that causes alteration of molecular systems such as decreasing soluble guanylate cyclase, nitride oxide production and increasing inactive nitride oxide ${ }^{7,8}$. Those pathways evoked the declining of cyclic Guanisine Monophosphate (cGMP) and triggering the activation of calcium ion that finally increasing systemic vascular resistance ${ }^{7}$. Reactivated oxidative stress is a pivotal substance in human lead intoxication that evokes hypertension and cardiovascular problems.

Beside affecting blood pressure regulation, lead can influence lipid synthesis through several molecular mechanism; disturbing feedbackinhibition from lipid metabolism, increasing the activity of 3-hydroxy-3-methylglutaryl co-enzyme A

${ }^{*}$ Author for correspondence 
(HMG CoA) reductase and HMG CoA synthase, as primary lipid metabolism enzyme in liver ${ }^{10,11}$. HMG CoA plays important role to change 2 Acteyl CoA to be HMG CoA, meanwhile HMG CoA reductase takes pivotal function to alter HMG CoA into mevalonate ${ }^{10}$. The next step, mevalonate will be changed to be several substances prior to be cholesterol component ${ }^{10 .}$ Lead takes action in changing lipid regulation in HMG CoA synthase and HMG CoA reductase pathways that resulting improvement of cholesterol activity in circulations ${ }^{12}$. Those bio-synthesis pathways plays important role to change lipid metabolism to regulate synthesis of Low Density Lipoprotein (LDL), High Density Lipoprotein (HDL) and Triglyceride (TG) particularly on people with long term exposure of environmental lead ${ }^{10-12}$.

As mentioned above, lead can cause multi-organ destruction for long time exposure particularly in lung, blood vessel and endocrine-metabolic pathways ${ }^{13}$. World Health Organization (WHO) has been stipulating limit threshold of lead that can be exposed by human is less than $10 \mu \mathrm{g} / \mathrm{dL}^{14}$. However, controlling of contamination sources should be concerned by policy maker to handle further impact of lead either human or environment.

\section{Methods}

A cross sectional study design was proposed as a research method to search correlation between lead exposure with blood pressure and lipid parameters. According to sample size calculation, there were 71 respondents who met the criteria such as willing to be study respondents, had history of staying around bus terminal for more than one year, aged more than 18 years old and 6 hours fasting prior to take data that was taken using consecutive sampling technique. There were two variables, lead as independent one and blood pressure parameter such as Systolic Blood Pressure (SBP) and Diastolic Blood Pressure (DBP), meanwhile lipid parameter consist of LDL, HDL and TG. Lead was measured by Atomic Absorption Spectophotometer (AAS), blood pressure was calculated by sphygmomanometer and lipid parameter was measured by automatic chemistry analyzer. Those variable were analyzed by linier regression technique with SPSS software $23^{\text {rd }}$ edition.

\section{Results}

Table 1 illustrated most of the respondents aged more than 40 years old $(67,6 \%)$, male $(71,8 \%)$, non smoking subjects $(53,5 \%)$, never use personal protective equipment $(85,9 \%)$, low education background $(50,7 \%)$, terminal workers $(71,8 \%)$ with length of works less than 10 years, duration of works more than 9 years, borderline level of LDL $(32,4 \%)$, medium level of HDL $(52,1 \%)$, normal level of triglyceride $(64,8 \%)$, hypertension stage $2(50,7 \%)$. Table 2 elaborated that respondents more than
Table 1. Baseline characteristic of respondents

\begin{tabular}{|c|c|c|}
\hline Variable & $\mathbf{n}$ & $\%$ \\
\hline \multicolumn{3}{|l|}{ Age } \\
\hline$\leq 40$ yo & 23 & 32,4 \\
\hline$>40$ yo & 48 & 67,6 \\
\hline \multicolumn{3}{|l|}{ Gender } \\
\hline Male & 51 & 71,8 \\
\hline Female & 20 & 28,2 \\
\hline \multicolumn{3}{|l|}{ Smoking } \\
\hline Yes & 33 & 48,5 \\
\hline No & 38 & 53,5 \\
\hline \multicolumn{3}{|c|}{ Personal protective equipment } \\
\hline Yes & 7 & 9,9 \\
\hline Sometimes & 3 & 4,2 \\
\hline No & 61 & 85,9 \\
\hline \multicolumn{3}{|l|}{ Education } \\
\hline Low & 36 & 50,7 \\
\hline High & 35 & 49,3 \\
\hline \multicolumn{3}{|l|}{ Occupation } \\
\hline Terminal workers & 51 & 71,8 \\
\hline Non terminal workers & 20 & 28,2 \\
\hline \multicolumn{3}{|l|}{ Length of works } \\
\hline$<10$ years & 41 & 57,7 \\
\hline$\geq 10$ years & 30 & 42,3 \\
\hline \multicolumn{3}{|l|}{ Duration of works } \\
\hline$<9$ hours per day & 34 & 47,9 \\
\hline$\geq 9$ hours per day & 37 & 52,1 \\
\hline \multicolumn{3}{|l|}{ Low density lipoprotein } \\
\hline Optimal & 10 & 14,1 \\
\hline Near optimal & 21 & 29,6 \\
\hline Borderline high & 23 & 32,4 \\
\hline High & 12 & 16,9 \\
\hline Very high & 5 & 7,0 \\
\hline \multicolumn{3}{|l|}{ High density lipoprotein } \\
\hline Low & 22 & 31,0 \\
\hline Medium & 37 & 52,1 \\
\hline High & 12 & 16,9 \\
\hline \multicolumn{3}{|l|}{ Triglyceride } \\
\hline Normal & 46 & 64,8 \\
\hline Borderline high & 3 & 4,2 \\
\hline High & 22 & 31,0 \\
\hline \multicolumn{3}{|l|}{ Blood pressure } \\
\hline Normal & 14 & 19,7 \\
\hline Hypertension stage 1 & 15 & 21,1 \\
\hline Hypertension stage 2 & 36 & 50,7 \\
\hline Crisis of hypertension & 6 & 8,5 \\
\hline
\end{tabular}


Table 2. Mean and standard of deviations of variables compared with baseline characteristic of respondents

\begin{tabular}{|c|c|c|c|c|c|c|c|}
\hline Variables & $\begin{array}{l}\operatorname{Mean} \pm \mathrm{SD} \\
\operatorname{Lead}(\mu / \mathrm{dL})\end{array}$ & $\begin{array}{c}\text { Mean } \pm \text { SD } \\
\text { SBP }(\mathrm{mmHg})\end{array}$ & $\begin{array}{c}\text { Mean } \pm \text { SD } \\
\text { DBP }(\mathrm{mmHg})\end{array}$ & $\begin{array}{c}\text { Mean } \pm \text { SD } \\
\text { LDL }(\mathrm{mg} / \mathrm{dL})\end{array}$ & $\begin{array}{c}\text { Mean } \pm \text { SD } \\
\text { HDL }(\mathrm{mg} / \mathrm{dL})\end{array}$ & $\begin{array}{c}\text { Mean } \pm \text { SD } \\
\text { TG }(\mathrm{mg} / \mathrm{dL})\end{array}$ & $\mathbf{n}$ \\
\hline \multicolumn{7}{|l|}{ Age } & \\
\hline$\leq 40$ yo & $0,26 \pm 0,41$ & $121,3 \pm 25,2$ & $80,8 \pm 12$ & $125,5 \pm 33$ & $50,1 \pm 12,4$ & $145,3 \pm 111,6$ & 23 \\
\hline$>40$ yo & $0,33 \pm 0,75$ & $152,3 \pm 146,1$ & $89 \pm 18,6$ & $138,5 \pm 33,9$ & $45,4 \pm 10,7$ & $169 \pm 95,1$ & 48 \\
\hline \multicolumn{7}{|l|}{ Gender } & \\
\hline Male & $0,25 \pm 0,45$ & $148,2 \pm 143,6$ & $84,8 \pm 12,1$ & $138,5 \pm 33,4$ & $45,1 \pm 9,2$ & $180 \pm 106,3$ & 50 \\
\hline Female & $0,45 \pm 1$ & $128,3 \pm 28,4$ & $90,2 \pm 25,3$ & $124,3 \pm 34,1$ & $51,3 \pm 14,7$ & $116,8 \pm 96$ & 21 \\
\hline \multicolumn{7}{|l|}{ Smoking } & \\
\hline Yes & $0,33 \pm 0,76$ & $127,9 \pm 27$ & $84,5 \pm 18,8$ & $140,2 \pm 36$ & $45,5 \pm 10,2$ & $168,4 \pm 94,7$ & 48 \\
\hline No & $0,27 \pm 0,37$ & $172,3 \pm 209,6$ & $90,4 \pm 12,2$ & $122,0 \pm 25,9$ & $49,9 \pm 13,2$ & $146,6 \pm 112,6$ & 23 \\
\hline \multicolumn{7}{|c|}{ Personal protective equipment } & \\
\hline Yes & $0,09 \pm 0,18$ & $124 \pm 27,5$ & $80 \pm 16,3$ & $123,4 \pm 24,1$ & $39 \pm 7$ & $182,9 \pm 96,2$ & 10 \\
\hline No & $0,35 \pm 0,7$ & $145,3 \pm 130,4$ & $87,4 \pm 17,1$ & $136,1 \pm 35,1$ & $48,2 \pm 11,5$ & $157,8 \pm 101,6$ & 61 \\
\hline \multicolumn{7}{|l|}{ Education background } & \\
\hline Low & $0,45 \pm 0,87$ & $155,5 \pm 171,8$ & $85,8 \pm 20,8$ & $133,4 \pm 29,3$ & $47,9 \pm 11,9$ & $149,8 \pm 90,2$ & 35 \\
\hline High & $0,17 \pm 0,31$ & $129,4 \pm 21,7$ & $86,9 \pm 12,8$ & $135,1 \pm 38,4$ & $46 \pm 11$ & $172,6 \pm 109,8$ & 36 \\
\hline \multicolumn{8}{|l|}{ Occupation } \\
\hline Non terminal workers & $0,3 \pm 0,73$ & $146,9 \pm 140$ & $85,5 \pm 18,4$ & $135,2 \pm 34,8$ & $44 \pm 9,6$ & $178,5 \pm 106,4$ & 53 \\
\hline Terminal workers & $0,34 \pm 0,4$ & $128,6 \pm 21,8$ & $88,8 \pm 12,7$ & $131,5 \pm 32,3$ & $55,5 \pm 12,2$ & $110,8 \pm 58,2$ & 18 \\
\hline \multicolumn{7}{|l|}{ Length of works } & \\
\hline$<10$ years & $0,28 \pm 0,80$ & $155,2 \pm 171,4$ & $88,1 \pm 21,5$ & $128,5 \pm 31,1$ & $47 \pm 11,4$ & $166,1 \pm 107,6$ & 35 \\
\hline$\geq 10$ years & $0,34 \pm 0,49$ & $129,7 \pm 24,7$ & $84,7 \pm 11,3$ & $139,9 \pm 36,1$ & $46,9 \pm 11,6$ & $156,7 \pm 94,6$ & 36 \\
\hline \multicolumn{7}{|l|}{ Duration of works } & \\
\hline$<9$ hours per day & $0,34 \pm 0,81$ & $151,5 \pm 160,2$ & $87,7 \pm 19,6$ & $136,2 \pm 36,3$ & $45,3 \pm 10,8$ & $172,4 \pm 115,9$ & 40 \\
\hline$\geq 9$ hours per day & $0,27 \pm 0,41$ & $130,4 \pm 27,7$ & $84,7 \pm 13,3$ & $131,8 \pm 31,1$ & $49 \pm 12$ & $147 \pm 75,9$ & 31 \\
\hline
\end{tabular}

40 years old have significantly higher level of lead, systolic and Diastolic Blood Pressure, as well as the level of LDL, HDL and TG. Male gender has higher level of LDL, HDL and TG than female. Smoking behavior has influenced on lead level, LDL, HDL and TG yet non smoking respondents have impacted on blood pressure level. Never wearing masker as personal protective equipment has specific impacted on level of lead, blood pressure and lipid level. Low of educational background has increased of lead level and blood pressure. The occupation status of being terminal workers has higher lead level and blood pressure. Length of works more than 8 years have increased lead level and LDL, HDL, TG level. The last variable, duration of works more than 9 hours per days has low level of lead, blood pressure and lipid level than more than the less than 9 hours per day respondents.

Based on Table 3 claimed that lead exposure has correlation with the entire variables ( $p$ value $<0,05$ ), meanwhile $r$ value and R square were found that SBP ( $\mathrm{r} 0.33$ and R square 0.11 ),
Table 3. Linier regression result of correlation lead exposure with variables

\begin{tabular}{|l|c|c|c|c|}
\hline Variables & $\mathbf{n}$ & P value & $\mathbf{r}$ & R square \\
\hline Systolic & 71 & 0,004 & 0,33 & 0,110 \\
\hline Diastolic & 71 & 0,001 & 0,37 & 0,138 \\
\hline LDL & 71 & 0,002 & 0,35 & 0,128 \\
\hline HDL & 71 & 0,001 & 0,37 & 0,139 \\
\hline TG & 71 & 0,002 & 0,36 & 0,130 \\
\hline
\end{tabular}

DBP (r 0.37 and R square 0.138 ), LDL (r 0.35 and R square 0.128 ), HDL (r 0.37 and R square 0.139) and TG r 0.36 and $\mathrm{R}$ square 0.130 ). According to coefficient correlation, it could be be concluded that lead exposure has significant correlation with the increasing of systolic, diastolic, LDL, HDL and TG level while R level reflected the number of contribution of lead exposure on those variables. 


\section{Discussion}

Lead exposure has significant effects on the cardiovascular problems through blood pressure regulation alteration. In our study, it was found that long-term lead exposure had strong correlation with Systolic and Diastolic Blood Pressure. In addition, almost our respondents got hypertension (80, $3 \%$ ), either non terminal workers (mean SBP 146,9 and DBP 85,5 ) or terminal employees (mean SBP 128,6 and DBP 88,8 ). Despite evidence of lead induced hypertension was still debatable, several researches claimed that lead exposure induced hypertension. In our study claimed that lead exposure increases SBP around $11 \%$ and DBP 13, 8\%. A systematic review claimed that lead is positively induced cardiovascular outcome including hypertension, ischaemia heart diseases, peripheral arterial diseases and stroke despite several studies conducted in animal model ${ }^{15}$. The study concluded doseresponse relationship blood lead level $<5 \mu \mathrm{g} / \mathrm{dL}$ has associated with cardiovascular effects ${ }^{15}$. Two pathways that had been proven regarding lead as a risk factor of cardiovascular diseases are mechanism through accelerated systolic blood pressure and the damage of renal function. Mean while, another study claimed that lead is a metal that contributes as risk factor of atherosclerosis as the result of lead-induced stress oxydative and inflammation process in blood vessels ${ }^{15-19}$. Another study explained the other potential mechanism is stimulation of renin angiotens in system, renal interstitial inflammation, nuclear factor and cell expressing angiotensin II, down regulation of nitric oxide and soluble guanylate cyclase that can result in increased of vascular tone and peripheral vascular resistance $\mathrm{e}^{16,18-20}$.

On several studies claimed that lead exposure correlates with lipid parameter changes such as LDL, HDL and TG. Our study clearly declared that lead induced lipid alteration among respondents that can be proven by statistical analysis. In addition, almost all respondents got increasing number of LDL, HDL and TG in spite of average lipid parameters among non-terminal workers were more prevalence than terminal employees, because the lipid parameters were also influenced by food intake, lengths of fasting and physical activity. Meanwhile, we had given informed consent to respondents for at least fast at least 6 hours prior to the data obtaining, to prevent measurement bias. However, the correlation between lead exposure and lipid parameter was significant. Lead induced lipid adaptation via enzymatic process in liver involving 3-hydroxy-3-methylglutaryl co-enzyme A (HMG CoA) reductase and HMG CoA synthase ${ }^{10,11}$. The result is similar with several studies that showed the intervention of lead exposure on rats disclose alteration of lipid metabolism. In spite of different of subjects that study has strengthened previously study about lead. Another study illustrated that lead was not only interfered lipid metabolism but also the serum alpha tocopherol and anti oxidant status, yet was still being debatable, it must be taken as primary reference beside cholesterol mechanism theory ${ }^{21,22}$. Study of correlation between chronic lead exposure and lipid metabolism is interesting topic but only few publications that concentrate on human body mechanism - most of them are animal studies.

Finally, this study also has limitation such as observational method could not be predicted between exposure and outcome, further cohort or experimental studies are needed to prove the association of lead exposure with cardiovascular or metabolic factors. The second one was monitoring respondents. Prior to data obtaining, we visited the respondents to give informed consents and explanation for fasting at least 6 hours before taking data and to remind them not to take breakfast in the morning before the examination. This action was conducted to avoid bias in examination.

\section{Conclusion}

Lead is an essential element that is widely used for industry. But, it also has appalling impact on both environment and the exposure on human. In human factor, it has significant correlation on blood pressure and lipid metabolism, as shown by the research result above. The precise mechanism of lead was interfering the blood pressure involved reactive oxygen species, kidney toxicity and renin angiotensin aldosteron system. Meanwhile, lipid alteration on chronic lead exposure was associated by enzymatic process through inhibition of HMG CoA synthase and reductase. Public health concern should be proposed by the policy maker to handle chronic impact on human such as controlling of air pollution, regulation of using lead in industry and personal protective equipment among workers or vulnerable population.

\section{Acknowledgment}

I am grateful to Faculty of Medicine, Universitas Islam Indonesia which granted funding support and proofreading to finish this study.

\section{References}

1. Abadin H, Ashizawa A, Stevens YW, Llados F, Diamond G, Sage G. Toxicology profile for lead. Atalanta: Agency for Toxic Substances and Disease Resgitry U.S. Department of Health and Human Services; 2007.

2. Lange J. Lead: An environmental neurotoxic agent. J Headache Pain Manag. 2017; 2(No.3:13):1-2. https://www.researchgate. net/publication/321752254 
3. Sciences NI of EH. Lead and your health. https://www.niehs.nih. gov/health/materials/lead_and_your_health_508.pdf

4. Park SK, Schwartz J, Weisskopf M, Sparrow D, Vokonas PS, Wright RO. Low-level lead exposure, metabolic syndrome and heart rate variability: The VA normative aging study. Environ Heal Perpectives. 2006; 114(11):1718-24. PMid: 17107858 PMCid: PMC1665394. https://www.ncbi.nlm.nih.gov/pmc/ articles/PMC1665394/ https://doi.org/10.1289/ehp.8992

5. Pruss-üstün A, Fewtrell L, Landrigan PJ, Ayuso-mateos JL. Lead exposure. Comparative Quantification of Health Risks. Vol 2. Geneva: WHO; 194AD:1496-1539. https://www.apps.who. int $>$ iris $>$ bitstream $>9241580348$ _eng_Volume1

6. Lee D. Evidence of the possible harm of endocrine-disrupting chemicals in humans: Ongoing debates and key issues. Endocrinol Metab. 2018; 33:44-52. PMid: 29589387 PMCid: PMC5874194. https://www.ncbi.nlm.nih.gov/pmc/articles/PMC5874194/ https://doi.org/10.3803/EnM.2018.33.1.44

7. Vaziri N. Mechanisms of lead-induced hypertension and cardiovascular disease. Am J Physiol. 2008; 295(2):454-65. PMid: 18567711 PMCid: PMC2519216. https://www.ncbi.nlm. nih.gov/pmc/articles/PMC2519216/ https://doi.org/10.1152/ ajpheart.00158.2008

8. Furieri LB, Bra G, Vescovi A, Stefanon I, Vassallo DV, Vinı M. Chronic lead exposure increases blood pressure and myocardial contractility in rats. PLoS One. 2014; 9(5):1-9. PMid: 24841481 PMCid: PMC4026242. https://doi.org/10.1371/ journal.pone.0096900 https://journals.plos.org/plosone/article/ comments?id=10.1371/journal.pone.0096900

9. Costa D. Air pollution. Klaassen C, ed. Casarett and Doull's Toxicology the Basic Science of Poisons. seven. Kansas: McGraw Hill; 2008. p. 1119-50.

10. Khalil HA, Aljubori S, Abdul-aziz S, Yaqub A. Comparative study between exposed and non exposed individuals to lead in relation to lipid profile. Tikrit Med J. 2010; 16(1):129-37. https://www. iasj.net/iasj?func=fulltext\&aId=22061.

11. Allouche L, Hamadouche M, Touabti A, Khennouf S. Effect of long-term exposure to low or moderate lead concentrations on growth, lipid profile and liver function in albino rats. Department of Animal Physiology, Faculty of Nature and Life Sciences. Adv Biol Res (Rennes). 2011; 5(6):339-47. https://pdfs.semanticscholar. org/c5bf/3889426a40d072fc111b176235e8208820db.pdf

12. Sharma SV, Kumar P, Atam V, Verma A, Murthy RC. Lipid profiles with increase blood lead level: Risk of cardiovascular disease in battery workers of Lucknow City. J Indian Acad Forensic Med. 2012; 34(4):328-31. https://www.researchgate. net/publication $/ 287850673$

13. Assi MA, Noor M, Hezmee M, Haron AW, Yusof M, Sabri M. The detrimental effects of lead on human and animal health. Vet
Sorld. 2016; 9(6):660-71. PMid: 27397992 PMCid: PMC4937060. https://www.ncbi.nlm.nih.gov/pmc/articles/PMC4937060/ https://doi.org/10.14202/vetworld.2016.660-671

14. World Health Organization. Exposure to lead: A Major public health concern. 2019. www.who.int

15. Navas-acien A, Guallar E, Silbergeld EK, Rothenberg SJ. Lead exposure and cardiovascular Disease - A systematic review. Environ Heal Perpectives. 2007; 115(3):472-82. PMid: 17431501 PMCid: PMC1849948. https://www.ncbi.nlm.nih.gov/pmc/ articles/PMC1849948/ https://doi.org/10.1289/ehp.9785

16. Ekong EB, Jaar BG, Weaver VM. Lead-related nephrotoxicity: A review of the epidemiologic evidence. Int Soc Nephrol. 2006; 70:2074-84. PMid: 17063179. https://www.kidney-international .org/article/S0085-2538(15)51899-1/fulltexthttps://doi.org/10.1038/ sj.ki.5001809

17. Mutner P, Menke A, DeSalvo K, Rabito F, Batuman V. Continued decline in blood lead levels among adults in the United States. Arch Intern Med. 2005; 165:2155-61. PMid: 16217007. https://jamanetwork.com/journals/jamainternalmedicine/ fullarticle/486734 https://doi.org/10.1001/archinte.165.18.2155

18. Harari F, Sallsten G, Christensson A, Petkovic M, Hedblad B, Forsgard $\mathrm{N}$ et al. Blood lead levels and decreased kidney function in a population-based cohort. AJKD. 2018; 72(3):381-9. PMid: 29699886. https://www.ajkd.org/article/S0272-6386(18)30556-0/ fulltext https://doi.org/10.1053/j.ajkd.2018.02.358

19. Rehman K, Fatima F, Waheed I, Akash MSH. Prevalence of exposure of heavy metals and their impact on health consequences. J Cell Biochem. 2018; 119:157-84. PMid: 28643849. https:// onlinelibrary.wiley.com/doi/abs/10.1002/jcb.26234 https://doi .org/10.1002/jcb.26234

20. Bernardo RI, Sindhu RK, Quiroz Y, Vaziri ND. Chronic exposure to low doses oflead resultsin renal infiltration of immune cells, NF-KB activation and over expression of tubulointestinal angiotensin II. Antioxidants Redox Signal. 2005; 7(3):1269-74. PMid: 16115032. https://www.liebertpub.com/doi/abs/10.1089/ars.2005.7.1269 https://doi.org/10.1089/ars.2005.7.1269

21. Ademuyiwa O, Ugbaja RN, Idumebor F, Adebawo O. Plasma lipid profiles and risk of cardiovascular disease in occupational lead exposure in Abeokuta, Nigeria. Lipids Health Dis. 2005; 7(4):17. PMid: 16191200 PMCid: PMC1253530. https://lipidworld. biomedcentral.com/articles/10.1186/1476-511X-4-19. https:// doi.org/10.1186/1476-511X-4-19

22. Antonowicz J, Andrzejak R, Lepetow T. Influence of heavy metals, especially lead on lipid metabolism, serum alpha-tocopherol level, total antioxidant status and erythrocyte redox status of copper smelter workers. J Anal Chem. 1998; 361:365-7. https:// doi.org/10.1007/s0021600509061 